\title{
THE BUMPY ROAD TO RULE OF LAW ENFORCEMENT: THE COMMISSION'S 2020 ANNUAL RULE OF LAW REPORT
}

\begin{abstract}
The paper assesses whether the von der Leyen Commission could give a realistic picture of the state of the rule of law in its first ever Rule of Law report of September 2020. On the plus side, the Commission starts with a clear definition of the rule of law, dispelling any fabricated arguments about the vagueness or even uselessness of the concept. The Commission promises to make the reporting exercise a regular one, treating Member States on an equal basis. The broad selection of relevant subject matters covered allows the reader to gain an overview of where Europe stands with regard to the rule of law. On the minus side the Commission aims at preventing violations and to provide a platform for dialogue - concepts incomprehensible and irrelevant in countries where state capture already happened. The report at times tries to give a qualitative analysis, but when it comes to systemic breaches, it fails to give the necessary context, and to connect the dots. But since all the national reports have enumerations of negative and positive developments, just by reading the Annual Reports one does not grasp how hybrid authoritarian regimes are qualitatively different from resilient democracies. On the side of authoritarian regimes, this approach also fuels whataboutery. Finally, the success of any monitoring exercise will depend on whether the response prong of the EU's rule of law enforcement mechanism manages to attach dissuasive and efficient consequences in due time to values' violations.
\end{abstract}

\section{Keywords}

Rule of law; Article 2 TEU; European values; European Commission; European Union; Annual Rule of Law Report

The concept of liberal democracy is in danger and the tools used to destroy it are legal. Legalistic, but in violation of the rule of law in several EU Member States. As Professor Mirosław Wyrzykowski put it, it is both 'trivially simple, and trivially effective' to destroy constitutionalism. 'The state loses its sovereignty because a state whose constitutional authorities violate the constitution is not a sovereign state. A 'technological sequence' of the destruction of the constitutional state is being created, in which all state bodies, institutions and procedures are involved in turn.' Institutions and entities that were designed to checks the government - be it a constitutional court, or-

${ }^{1}$ M. Wyrzyкowski, 'The ghost of an authoritarian state stands at the door of your home', VerfBlog 26 February 2020, https://verfassungsblog.de/the-ghost-of-an-authoritarian-state-stands-at-the-door-of-your-home/ (all links last accessed on 24 October 2020), given at the 48th European Presidents' Conference of Lawyers 2020 in Vienna. I take some pride in having a joint experience with Professor Wyrzykowski in this regard. For my speech at the 47 th European Presidents' Conference of Lawyers see P. BÁRD, 'Contribution to the rule of law debate at the 47th European Presidents' Conference', Österreichisches Anwaltsblatt 21.5 (2019), pp. 307-309, https://www.rechtsanwaelte. at/fileadmin/user_upload/Anwaltsblatt/19_anwbl05.pdf. 


\section{Petra Bárd}

dinary courts, media, civil society or academia - are captured, and as a consequence they cannot fulfil their original functions. The question for this paper is, whether the European Commission, as an external forum of militant democracy, and guardian of the Treaties, which is based on an allegedly shared understanding of respect for the rule of law, democracy, fundamental rights and other values, ${ }^{2}$ can put a halt to rule of law backsliding and prevent dismantling of concepts European Union law and the European project are based on.

\section{Bumpy Beginnings}

High, but mixed expectations surrounded the Commission's 2020 Annual Rule of Law Report.

Expectations were huge, since defence for the rule of law is existential for the EU. Violation of the rule of law in any Member State is an EU matter. Should elections not be fair in a Member State, all EU citizens and residents will to some extent suffer due to the given state representatives' participation in the EU's law-making mechanism. Also, the EU's claim to play a pioneering role in the exportation of EU values will be seen as hypocritical, if it cannot take care of its rule of law violations internally. What is more, should rule of law backsliding remain without consequences in one country, other states will follow suit, or in other words rule of law backsliding will become contagious. One rotten apple spoils the whole barrel. Once the values of Article 2 TEU such as democracy, the rule of law and human rights - are not respected, the essential presumptions behind the core of the Union do not hold any more. Respect for the rule of law is essential for an investment-friendly environment and in general for the internal market to be functional. It is also vital for the effective cross-border judicial cooperation in criminal matters. To give a very vivid example, courts in Amsterdam and Karlsruhe refuse to surrender suspect to Poland - strictly speaking in violation of EU law - in fear of becoming complicit in human rights, especially fair trial violations, if suspects were tried by courts that are no longer independent. ${ }^{3}$

But not only were expectations high, they were also mixed, due to the bumpy start of the Ursula von der Leyen Commission. Many held her too weak on the rule of law for a Commission President. ${ }^{4}$ Still she was voted in - with the support of the two autocratic governments against whom Article 7 TEU procedures are and were at the time pending. In her first interview given on the rule of law, ${ }^{5}$ in an effort to use a reconciliatory tone, she belittled and framed the problem of systemic rule of law violations completely wrong: in her 'nobody is perfect' interview, instead of pointing to substantive rule of law issues, she claimed that there were dividing lines between Eastern and Western member states of the European Union, and Eastern states' viewpoints were not respected. This very much corresponds to the repeated critical state-

${ }^{2}$ Article 2 Treaty on the European Union.

${ }^{3}$ P. BÁRD \& J. MoRIJN, 'Luxembourg's unworkable test to protect the rule of law in the EU: Decoding the Amsterdam and Karlsruhe Courts' post-LM rulings (Part I)', VerfBlog 18 April 2020, https://verfassungsblog.de/luxembourgs-unworkable-test-to-protect-the-rule-of-law-in-the-eu/; IDEM, 'Domestic Courts Pushing for a Workable Test to Protect the Rule of Law in the EU: Decoding the Amsterdam and Karlsruhe Courts' post-LM Rulings (Part II), VerfBlog 19 April 2020. https://verfassungsblog.de/domestic-courts-pushing-for-a-workable-test-to-protect-therule-of-law-in-the-eu/.

${ }^{4}$ C. Wergin \& Ch. B. Schiltz, 'Die Enttäuschung war am Schluss überwältigend und fast ausnahmslos', Welt 10 July 2019, https://www.welt.de/politik/ausland/article196681411/Ursula-von-der-Leyen-auf-Werbetour-DieEnttaeuschung-war-ueberwaeltigend.html.

${ }^{5}$ D. Brössler, 'Von der Leyen im Interview: "Nicht die schärfste Drohung an den Anfang"', Süddeutsche Zeitung 18 July 2019, https://www.sueddeutsche.de/politik/von-der-leyen-eu-interview-1.4530615. 
ments originating from CEE politicians claiming that the dividing line between the friends of the rule of law and its enemies is too often framed as an East-West divide. But we dispelled this myth showing that the various attempts for an alternative Eastern understanding of the rule of law are academically dishonest attempts for justifying rule of law backsliding. ${ }^{6}$ National differences of course do exist, but - agreeing with the succinct explanation by Kovács and Tóth -, there is 'a crucial difference between a dialogue among constitutionalists within the framework of constitutional democracy and a dialogue with delegates of a constitutional simulacrum. ${ }^{7}$ The Commission should recognize that these claims do not form parts of multi-level constitutionalism, and shall be deconstructed as simple delusions that are only created either to escape liability for violating the rule of law and democracy or to gain more time in doing so. The Commission should make clear that these concepts cannot be used to go against European minimum standards, neither can they be employed as a carte blanche authorization to overwrite EU laws.

Apart from giving in to those who equal illiberalism with an alternative understanding of the rule of law, baptising the migration portfolio's holder as Vice-President for 'Protecting our European way of Life' was also heavily criticized for normalising hate mongering, xenophobia, and giving in to the far right in general. ${ }^{8}$ Some other concessions Ursula von der Leyen made when designing the future Commission reinforced the suspicion that she was willing to compromise the rule of law for political benefits. Both member states currently subject to Article 7(1) TEU proceedings got the positions they wished for. In the case of Poland this was agriculture, and Hungary got the portfolio for neighbourhood and enlargement. The Commissioner is entrusted with overseeing in candidate and neighbouring countries the rule of law, the fight against corruption, the role of an independent media and civil society - in other words, values that his government has systematically and deliberately undermined.

\section{Prevention, Dialogue and Even More Dialogue}

Let us now turn to what the Commission did to protect he rule of law from a substantive point of view. Here the Commission's Communication on the State of play and possible next steps of April $2019^{9}$ and its Rule of Law Blueprint for Action of July $2019^{10}$ provide some guidance.

The Commission's plans follow a very clear structure of rule of law promotion, prevention of violations and a response prong. Both Ursula von der Leyen in the already referenced interview titled 'Not the worst threat right at the beginning', and the Blueprint emphasize that response must be a last resort. Prioritizing rule of law promotion and prevention goes hand in hand with demand for more dialogue. Justice Commis-

${ }^{6}$ L. Pech, J. Grogan, \& al., 'Unity and diversity in national understandings of the rule of law in the EU' (2020) https://reconnect-europe.eu/wp-content/uploads/2020/05/D7.1-1.pdf; R. D. KeLEMEN \& L PECH, 'Lessons from Hungary and Poland', Reconnect Working Paper No. 2, September 2018, https://reconnect-europe.eu/wp-content/ uploads/2018/10/RECONNECT-WorkingPaper2-Kelemen-Pech-LP-KO.pdf.

${ }^{7}$ K. Kovács \& G. A. Tóтн, 'The age of constitutional barbarism', VerfBlog 7 September 2019, https://verfassungsblog.de/the-age-of-constitutional-barbarism/

${ }^{8}$ S. IN 'T Veld, 'Threat to "European way of life" is not migrants. It's populists', Politico 12 September 2019, https://www.politico.eu/article/populist-threat-to-european-way-of-life-sophie-int-veld-ursula-von-der-leyen/.

${ }^{9}$ https://ec.europa.eu/info/sites/info/files/rule_of_law_communication_en.pdf.

${ }^{10}$ Communication from the Commission to the European Parliament, the European Council, the Council, the European Economic and Social Committee and the Committee of the Regions, Strengthening the rule of law within the Union: A blueprint for action, Brussels 17 July 2019, COM(2019) 343 final. 


\section{Petra Bárd}

sioner Didier Reynders emphasized that discussion is the key to rule of law problems ${ }^{11}$ and he was also the mastermind behind the Belgian-German proposal for a Periodic Peer Review of the Rule of Law in the EU, ${ }^{12}$ setting up a regular interactive discussion on an expert level, and on a political level in the General Affairs Council. The discursive approach might indeed work well with member states that respect the rules of the game and in the overall assessment adhere to the concept of liberal democracy. But when it comes to systemic rule of law backsliding, the strength of any EU reaction will depend on 'response' prong attaching dissuasive consequences to systemic and deliberate violations of values the EU is based on. More dialogue will not help with notorious rule of law violators. The main lesson to be learned after a decade of rule of law violations in Hungary and with several member states joining the illiberal club is that dialogue is only abused by illiberal regimes to gain more time to compete constitutional capture. There should be room for member states under review to present their arguments and pieces of evidence underpinning their positions. But once it becomes clear that a government acts in bad faith, the Commission should acknowledge that further so-called dialogue - which is more a dialogue of the deaf ${ }^{13}$ - will only result in granting sufficient time to complete the capture of state institutions and solidifying an authoritarian state. This is the lesson to be learned from the pre-Article 7 procedure $v i s-\grave{a}$-vis Poland for capturing its Constitutional Tribunal. After months of fruitless negotiations, the Commission formalized its concerns in its Opinion of 1 June 2016, ${ }^{14}$ and a complementary recommendation was adopted on 21 December $2016,{ }^{15}$ which gave the Polish government another two months to comply. Unsurprisingly, the Polish government failed to respect EU demands; instead it challenged the legitimacy and objectivity of the process, downplayed its importance and before the procedure would have come to an end, it entirely captured the Constitutional Tribunal. Another seven months later, on 26 July 2017, the Commission could only report that the recommendations had been disregarded and several other measures had been introduced to capture ordinary courts, too. ${ }^{16}$

In 2020 President von der Leyen in her first State of the Union address, entirely detached from reality, still pretends everything was all right on the rule of law front and the Commission's main task was to 'prevent' potential violations. She mentions a 'starting point (...) to ensure there is no backsliding', after a decade long systemic dismantling of the rule of law in Hungary, five years in Poland, Bulgaria and others following suit. ${ }^{17}$ She shyly refrains from mentioning the two ongoing Article 7(1) proceedings, one of which was initiated by the Commission itself.

The 2020 Annual Rule of Law Report mirrored this positive approach building on dialogue and preventing problems from emerging. The Commission welcomed the

${ }^{11}$ See the speech delivered at the Center for European Policy Studies, 'CEPS - Europe, back on track' by Minister Didier Reynders, 23 February 2018, https://diplomatie.belgium.be/en/newsroom/news/2018/ceps_europe_ back_on_track.

${ }_{12}$ A. Brzozowski, 'Belgium, Germany make joint proposal for EU rule of law monitoring mechanism', 19 March 2019, https://www.euractiv.com/section/justice-home-affairs/news/belgium-germany-make-joint-proposalfor-eu-rule-of-law-monitoring-mechanism/.

${ }^{13}$ L. Pech \& K. L. Scheppele, 'Poland and the European Commission, Part I: A dialogue of the deaf?', VerfBlog 3 January 2017, https://verfassungsblog.de/poland-and-the-european-commission-part-i-a-dialogue-of-the-deaf/.

${ }^{14}$ Memo 'Commission opinion on the rule of law in Poland and the rule of law framework: Questions \& Answers', 1 June 2016.

${ }^{15}$ Commission Recommendation regarding the rule of law in Poland complementary to Commission Recommendation (EU) 2016/1374, 2016 C(2016) 8950 final, 21 December 2016.

${ }^{16}$ Press release, European Commission acts to preserve the rule of law in Poland, 26 July 2017.

${ }^{17}$ R. D. Kelemen, 'Von der Leyen is weak on rule of law', Politico 21 September 2020, https://www.politico.eu/ article/ursula-von-der-leyen-weak-rule-of-law/. 
'open dialogue with the Member States' considered that the report would prevent rule of law problems from emerging or deepening, and that it would promote 'a robust political and legal rule of law culture throughout the EU'. ${ }^{18}$ In order to pretend that 'prevention' is still meaningful, the Commission's Rule of Law Report 'presents the situation in Poland or Hungary as one where a largely intact system of constitutional checks and balances is being attacked, [whereas i] n fact, in both countries key ones were already removed a while ago and the authoritarian developments are already institutionally entrenched. ${ }^{\prime 19}$ EU Commissioner for Values and Transparency Jourová, during the presentation of the Annual Rule of Law Report, emphasized dialogue even after the Hungarian Prime Minister suspended all relations with her and requested her to resign. ${ }^{20}$

The Commission talks about 'prevention' in the year, when Freedom House's Nations in Transit report proves that Hungary was no longer a democracy, ${ }^{21}$ and the report of the Varieties of Democracy (V-Dem) Project classifies Hungary as autocratic. ${ }^{22}$ Whichever index assessing subparts of the rule of law are consulted, whether the civil society organisation sustainability index, ${ }^{23}$ or the academic freedom index, ${ }^{24}$ Hungary is lagging behind and a rapid decline is diagnosed. So the Commission pretends to uphold values at a time, when they have long been lost at least in some parts of the EU. As Daniel R Kelemen put it in a much forceful and creative way, 'with one democracy under its guard already burned to the ground and another in the midst of a three-alarm fire, the European Commission published an obscurantist treatise on the importance of fire safety and on warning signs of fire risk. ${ }^{25}$

\section{Assessment of the Assessment}

Moving beyond political rhetoric and framing the problem of rule of law as a potential or existing danger, let us assess whether the first ever Commission Rule of Law report could give a realistic picture of the state of the rule of law in the EU. On the plus side, one should praise the Commission for starting on page 1 with a very clear definition

\footnotetext{
${ }^{18}$ Communication from the Commission to the European Parliament, The Council, The European Economic and Social Committee and the Committee of the Regions, 2020 Rule of Law Report The rule of law situation in the European Union COM(2020) 580 final, 30 September 2020.

${ }^{19}$ D. Hegedüs, 'The European Commission's missed rule-of-law opportunity', 1 October 2020, https://www. gmfus.org/blog/2020/10/01/european-commissions-missed-rule-law-opportunity.

20 S. Zsiros \& J. Gill, 'Hungary calls for EU's Jourova to quit over "sick democracy" comment', Euronews 29 September 2020. https://www.euronews.com/2020/09/29/hungary-calls-for-eu-commissioner-jourova-to-resignover-derogatory-comments?fbclid=IwAR2AlBNXrX7p1ZVDHiG2VUe-fgaUxoWFd1yhl7SqqRDCrNpjBvViyD$5 \mathrm{nmA}$. Commissioner Jourová made a play of words, and said that Hungary was not an 'illiberal', rather an 'ill democracy'. M. Becker \& P. MÜller, 'EU Commission Vice President on the Rule of Law in Europe "The Condition of Hungary's Media Landscape Is Alarming”', Spiegel 29 September 2020, https://www.spiegel.de/international/europe/eu-commission-vice-president-on-the-rule-of-law-in-europe-the-condition-of-hungary-s-media-landscapeis-alarming-a-1d762f7d-b4a0-4cb8-b7a4-1a1ca5f4f9fa.

${ }^{21}$ Freedom House, Dropping the Democratic Façade, https://freedomhouse.org/report/nations-transit/2020/ dropping-democratic-facade.

${ }^{22}$ S. Kalberer, 'V-Dem: Autocratization continues but resistance grows', 25 March 2020, https://www.democracywithoutborders.org/13023/v-dem-autocratization-continues-but-resistance-grows/.

${ }^{23} 2018$ Civil Society Organization Sustainability Index Central and Eastern Europe and Eurasia 22nd Edition - September 2019, https://www.fhi360.org/sites/default/files/media/documents/resource-csosi-2018-reporteurope-eurasia.pdf.

${ }^{24}$ K. Kinzelbach, I. Saliba, J. Spannagel \& R. Quinn, 'Free Universities', March 2020, https://www.gppi.net/ media/KinzelbachEtAl_2020_Free_Universities.pdf.

${ }^{25}$ R. D. Kelemen, 'Op-Ed: You can’t fight autocracy with toothless reports', 6 October 2020, https://eulawlive. com/op-ed-you-cant-fight-autocracy-with-toothless-reports-by-roger-daniel-kelemen/.
} 


\section{Petra Bárd}

of the rule of law inspired by the Venice Commission's Rule of Law checklist of $2011^{26}$ and the definition offered by Commission already in $2014 .{ }^{27}$ Reporting will be a regular exercise, treating Member States on an equal basis. The selection of subject matters covered (justice, corruption, media, separation of powers) make the Member States to some extent comparable, but at least gives an overview of where Europe stands with regard to the rule of law.

As we argued earlier, a 'rule of law evaluation shall be a nuanced exercise, and particular care shall be taken to make a contextual analysis and not to rely on a standardised benchmarking system that could veil or blur problems - thereby doing more harm than good. ${ }^{28}$ The report at times tries to give a qualitative analysis, but when it comes to systemic breaches, it fails to give the necessary context, and to connect the dots. Although it does give a devastating picture of notorious rule of law violators, the scale and especially the systemic nature of the problem of state capture is not visible. The report offers a long enumeration a number of separate, seemingly disconnected issues. But since all the national reports have enumerations of negative and positive developments, just by reading the Annual Reports one does not grasp how hybrid authoritarian regimes are qualitatively different from resilient democracies. On the side of authoritarian regimes, this approach fuels whataboutery.

\subsection{Whataboutery}

Hungary, which is considered the first non-democratic regime in the EU will serve as a test case. It took whataboutery to the extreme, with the Hungarian Justice Minister launching a website dedicated to rule of law issues in other countries from abolishing referenda in the Netherlands to the treatment of the Sami minority in Finland. ${ }^{29}$ Interestingly, the other main violator of Article 2 TEU values, Poland is not mentioned - feeding the conspiracy theory that the rule of law is a war waged by the West against the East, or that double-standards are used against old Member States and those that acceded in 2004 or after. Such a misperception is also supported by EU politicians, including Ursula von der Leyen (see her already referenced 'nobody is perfect' interview). Commissioner Jourová, in an effort to show that Western states are indeed imperfect, too, misconstructs a Luxembourg case, where the CJEU held that German prosecutors were not independent judicial authorities for the sake of EU law, and could not issue European Arrest Warrants in the future, since they could be given instructions by the justice ministers. Commissioner Jourová claims that this was a clear weakness in terms of the rule of law. ${ }^{30}$ But it is not. Holding that German prosecutors were not independent enough to issue European arrest warrants, does not say anything about the quality of Germany's prosecutorial system. There are different, equally legitimate models for the prosecutor's office: although there is a trend for prosecutors to be independent from the executive, in some countries they are still subordinated to the government. It does not however mean that these latter countries have rule of law is-

${ }^{26}$ European Commission for Democracy through Law (Venice Commission) Report on the Rule of Law, Adopted by the Venice Commission at its 86th plenary session (Venice, 25-26 March 2011), Strasbourg, 4 April 2011 Study No. 512 / 2009 CDL-AD(2011)003rev.

${ }_{27}$ Press release, European Commission presents a framework to safeguard the rule of law in the European Union, 11 March 2014, http://europa.eu/rapid/press-release_IP-14-237_en.htm.

${ }^{28}$ P. BÁrd, S. Carrera, E. Guild \& D. Kochenov, 'An EU mechanism on democracy, the rule of law and fundamental rights', Brussels, Belgium: Center for European Policy Studies (2016).

${ }^{29}$ https://www.facebook.com/VargaJuditMinisterofJustice/?ref=page_internal.

${ }^{30}$ BeCKer \& MüLleR, 'The condition of Hungary's media landscape' (cit. n. 20). 
sues. As the Venice Commission put it: 'While the independence of judges and the judiciary in general have their origin in the fundamental right for persons to a fair trial (...) the independence of prosecutors and the prosecution system does not have such a common standard. ${ }^{31}$ '[T] he major reference texts allow for systems where the prosecution service is not independent from the executive. ${ }^{32}$ It is indeed an important issue whether ot not an authority can issue a European Arrest Warrant, and Germany might have falsely implemented the respective Framework Decision, but this transposition problem does not indicate a rule of law problem in the domestic setting. ${ }^{33}$

\subsection{Missing and misconstrued issues, failure to point at interlinked system errors}

In relation to Poland, the report is more comprehensive, but with regard to Hungary, it simply fails to mention the early steps of a decade-long autocratisation, such as the dismantling of the Hungarian Constitutional Court's independence. This is so despite the fact that the EU documented these developments well, for example in the $2013 \mathrm{Ta}-$ vares report. ${ }^{34}$

Without mentioning early instances of constitutional capture, and without the Report linking more recent events to these early ones, one cannot fully grasp the importance of matters that the Report does mention. One example is the Hungarian Parliament's 2019 omnibus law, which interfered into judicial appointments, and made sure that Constitutional Court justices without any experience in normal adjudication land at the top of the judicial hierarchy, in the Supreme Court. Another example is the new possibility granted to public authorities to challenge ordinary court decisions before the Hungarian Constitutional Court. Such rules of course violate legal security, but more importantly - and this is not clear from the Report - they extend the powers of the Hungarian Constitutional Court judges who were selected more for their loyalty than for their professional achievements by the majority of the Parliament, i.e. Fidesz MPs.

Another instance of no contextualization is the reference to judges being subject to negative narratives in the media. (p. 4) This is a much graver problem than that. The judicial system, court decisions and individual judges are attacked in the media. They have very few platforms for protecting themselves, and when they try to do so, they are blamed for engaging in politics. According Amnesty International, this had a chilling effect on judges, who are now even less likely than before to stand up for their independence, and they harbour diffidence and hostility against each other. ${ }^{35}$

Another instance mischaracterized and downplayed by the Hungarian Report is the compensation awarded to Roma victims of school segregation and compensation awarded to prisoners detained under inhuman conditions. The Report talks about 'Government and pro-government media outlets have criticis[ing these] judicial de-

${ }^{31}$ CDL-AD(2014)029, Opinion on the Draft amendments to the Law on the State Prosecutorial Council of Serbia, $\$ 7$.

${ }^{32}$ CDL-AD(2014)042, Interim Opinion on the Draft Law on the State Prosecution Office of Montenegro, $\$ 16$.

${ }^{33}$ 2002/584/JHA: Council Framework Decision of 13 June 2002 on the European arrest warrant and the surrender procedures between Member States - Statements made by certain Member States on the adoption of the Framework Decision, OJ L 190, 18 July 2002, p. 1-20.

${ }^{34}$ European Parliament, Committee on Civil Liberties, Justice and Home Affairs, On the situation of fundamental rights: standards and practices in Hungary (pursuant to the European Parliament resolution of 16 February 2012) (2012/2130(INI)), PE 508.211v04-00, Rapporteur: Rui TAVAREs, 25 June 2013.

${ }^{35} \mathrm{https} / /$ www.amnesty.hu/wp-content/uploads/2020/09/HUN_NGO_contribution_EC_RoL_Report_2020. pdf, p. 17. 


\section{Petra Bárd}

cisions' (p. 4) and lawyers fearing that this would 'undermine public trust and confidence in the justice system' (p. 5). But when it comes to the dismissing court decisions on the false ground that it was a provocation of the Soros-network, ${ }^{36}$ the most crucial matter is not the potential undermining of public trust. Much rather the Hungarian Report should have emphasized that prison conditions were so heinous that it resulted in a pilot judgment condemning Hungary. ${ }^{37}$ It should have mentioned that instead of rethinking its penal policy, the government continued to keep prisoners under heinous conditions, but it established a fast track compensation system outside the traditional judicial route to pre-empt further Strasbourg condemnations. ${ }^{38}$ It was precisely this system Fidesz itself created that was then presented as a 'prison business' of lawyers and their clients. ${ }^{39}$ So not only did the government let prisoners down by keeping prisoners in awful conditions, but they also out tricked the system, so that inmates could not be awarded compensation, neither as a result of European Court of Human Rights judgments, nor due to national judgments. What is more, the government incited to hatred against prisoners and by combining the two sets of cases successfully linked a 'Roma issue' with that of prisoners, thereby delegitimizing both. Finally, and most relevantly, in clear violation of separation of powers, the government straightforwardly overwrote court decisions, but the report entirely fails to mention that these court decisions were overwritten by Parliament. ${ }^{40}$

At times the Report cannot grasp the important problems, it fires in the air. With regard to corruption one may have expected the Commission to list all the OLAF reports and procedures indicating how much money was used against the rules (it only gives a number of procedures). Against this background it could have listed national procedures started in relation to the same amount of money. Instead we see that the problem is that asset declarations of senior civil servants and MPs are not systemically verified (p. 11) - which shows a great deal of naïveté in a country of strawmen, where the wealth of the childhood friend of the Prime Minister, gas fitter by profession, grows at an exponential speed.

The Report also uses extremely soft language. It says: 'The independence and effectiveness of the Media Council is at risk,' (p. 13) whereas in reality the Media Council was one of the first entities to be captured, which allowed media pluralism to be greatly damaged, which again made access to information and deliberative democracy impossible, and contributed to the fact that elections are not fair anymore, so even the thinnest understanding of the rule of law is violated. ${ }^{41}$

Finally, the Report illustrates a delicate issue: standards employed in democracies might not function for autocracies. An example is the praise for the adequate funding of the Media Authority (p. 13), whose independence however is not existent, quite to the contrary: it proactively supports government outlets and harnesses opposition ones. Is it really a virtue to finance well the enablers of one's own autocracy?

${ }^{36}$ NYG, Orbán: Engem már nyolcszor ölt meg Soros hálózata [Orbán: I was killed eight times by the Soros network], Index 17 January 2020, https://index.hu/belfold/2020/01/17/orban_engem_mar_nyolcszor_olt_meg_soros_halozata/.

${ }^{37}$ ECtHR, nos. 14097/12, 45135/12, 73712/12, 34001/13, 44055/13, and 64586/13 - Varga et al. v Hungary (Judgment of 10 March 2015).

${ }^{38}$ Cs. GYőRY, 'Fighting prison overcrowding with penal populism - First victim: the rule of law: new Hungarian law "suspends" the execution of final court rulings', VerfBlog 12 March 2020, https://verfassungsblog.de/fighting-prison-overcrowding-with-penal-populism-first-victim-the-rule-of-law/.

${ }^{39} \mathrm{http}: / /$ abouthungary.hu/prison-business/.

40 'Parliament suspends compensation payments to prisoners', 26 February 2020, http://abouthungary.hu/newsin-brief/parliament-suspends-compensation-payments-to-prisoners/

${ }^{41}$ J. A. Schumpeter, Capitalism, Socialism, and Democracy, New York 1950. 


\section{Conclusions}

All in all, the Commission engaged in another problem mapping exercise, for the better or worse. It enumerates many problem areas in all the Member States, but as shown through the example of Hungary, the first Member State declared a non-democracy, the Report uses too soft a language, mentions isolated cases without connecting the dots, often without context. This may feed whataboutery, downplay the problem, or even normalize it, in short may even be harmful. 'A reader not familiar with the situation in Hungary could hardly get the impression from the report that deliberate, wellorganized, years-long systemic attacks have taken place in these member states against the melting remnants of liberal constitutionalism and democracy. ${ }^{2}$

More importantly, the document does not foresee remedies, it solely aims to give an assessment of the rule of law situation in the Member States, which may later feed into procedures that are designed to respond to rule of law violations. Instead we suggest to reverse things, and take the response prong as a starting point, since without effective and dissuasive enforcement options, any attempt to strengthen and promote the rule of law is a futile exercise. And the EU should think about an effective response sooner than later, since later will be too late. It could reform Article 7 TEU procedures, make more frequent and more timely use of Article 7(1) TEU, and use it for what it is: a platform for discussion before rule of law backsliding happens. It could make better use of infringement procedures. For now, the Ursula von der Leyen initiated one single infringement procedure for rule of law violations, albeit Member States offered plenty of opportunities. The Commission could bundle cases, and point to the systemic nature of various problems. ${ }^{43}$ It could accelerate and prioritize infringement procedures, and make much better use of interim measures. ${ }^{44} \mathrm{EU}$ institutions could agree on automatic triggering of sanction procedures, and suspension of EU law instruments and concepts, which are based on the presumption that all Member States are respecting Article 2 TEU values. ${ }^{45}$ They could have a clear rule of law conditionality when distributing funds, ${ }^{46}$ and they could suspend the distribution of money to European political parties and European political foundations that harbour political parties disrespecting the rule of law. ${ }^{47}$ These are just some of the options the EU has available, or could make better use of, showing that institutions may become more creative and effective when it comes to the enforcement of the rule of law in the Member States, even within the existing Treaty framework..$^{48}$ Otherwise documents like the Commission's 2020 Annual Report turn into an autopsy of former democracies. It is the coroner who gives the best

${ }^{42}$ D. Hegedüs, 'The European Commission's missed rule-of-law opportunity', 1 October 2020, https://www. gmfus.org/blog/2020/10/01/european-commissions-missed-rule-law-opportunity.

${ }^{43} \mathrm{~K}$. L. SCHEPPELE, 'Enforcing the basic principles of EU law through systemic infringement actions from part ii - proposing new approaches', [in:] C. Closa \& D. Kochenov, Reinforcing Rule of Law Oversight in the European Union, Cambridge 2016, pp. 105-132

${ }^{44}$ A. ŚlEDZIŃSKA-Simon \& P. BÁRD, 'The teleos and the anatomy of the rule of law in EU infringement procedures', Hague Journal on the Rule of Law 11.2-3 (2019), pp. 439-445.

${ }^{45}$ Committee on Civil Liberties, Justice and Home Affairs, Report on the establishment of an EU Mechanism on Democracy, the Rule of Law and Fundamental Rights (2020/2072(INL)), Rapporteur: Michal ŠIMEČKA, A90170/2020, 29 September 2020, Annex, Point 20.

${ }^{46}$ R. MAŃKo \& M. SAPA£A, 'Protecting the EU budget against generalised rule of law deficiencies, EU legislation in progress 2021-2027', July 2020, https://www.europarl.europa.eu/RegData/etudes/BRIE/2018/630299/EPRS_ BRI(2018)630299_EN.pdf.

${ }^{47}$ J. MoRIJN, 'Responding to "populist" politics at EU level: Regulation 1141/2014 and beyond', International Journal of Constitutional Law 17.2 (April 2019), pp. 617-640.

${ }^{48}$ W. van BALlegooi, 'Addressing violations of democracy, the rule of law and fundamental rights, EPRS Ideas Paper Towards a more resilient EU', September 2020, https://www.europarl.europa.eu/RegData/etudes/ BRIE/2020/652070/EPRS_BRI(2020)652070_EN.pdf. 
diagnosis, it is only too late. It will be too late both for the countries where there are no more efficient internal checks on government anymore. But it will also be too late for the EU, for which a firm and clear stepping up against rule of law backsliding in the national setting would be existential. ${ }^{49}$ Professor Mirosław Wyrzykowski's warning borrowing the words of Marian Turski, the last living prisoner of Auschwitz - should apply to each one of us, but also to institutions we have created to uphold values and prevent arbitrariness of power: 'Thou shalt not be indifferent. ${ }^{50}$

Petra Bárd

\section{Petra Bárd}

Dr. habil. Petra Bárd LLM PhD is Associate Professor at Eötvös Loránd University, Faculty of Law, Department of Criminology in Budapest; Visiting Professor and Researcher at the Central European University's Legal Studies Department in Budapest and Vienna; and lectures at other universities across Europe including in Belgrade, Frankfurt and Vienna. She participates in numerous international research consortia, such as RECONNECT, a H2020 project on 'Reconciling Europe with its Citizens through Democracy and Rule of Law'; and is principle investigator of a research team targeting hate crimes, at the Hungarian Academy of Sciences. In her research and 200 pieces of academic publications - including several monographs - she targets issues at the intersection of the rule of law, human rights, EU criminal cooperation, mutual recognition and mutual trust.

\section{Petra Bárd}

Central European University

Legal Studies Department

Nádor u. 9.

1051 Budapest

Hungary

e-mail: bardp@ceu.edu

${ }^{49}$ T. T. Koncewicz, 'The existential jurisprudence of the Court of Justice of the European Union. An essay on the judicial incrementalism in defence of European first principles', [in:] Profesor Marek Safjan znany i nieznany. Ksiega jubileuszowa $z$ okazji siedemdziesiątych urodzin, Warszawa, pp. 223-240.

${ }^{50} \mathrm{M}$. Wyrzykowski, 'The ghost of an authoritarian state' (cit. n. 1). 